BIOKEMISTRI 20(1):17-22 (June 2008)

This article is downloadable online in PDF format

at http://www.bioline.org.br/bk

Printed in Nigeria

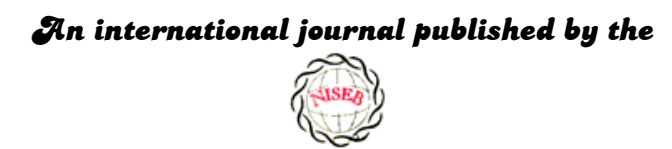

OVigerian Society for O̊xperimental \&iology

\title{
Effect of ethanol extract of Pyrenacantha staudtii leaves on carbontetrachloride induced hepatotoxicity in rats
}

\section{Chioma A. ANOSIKE*, Uchenna B. UGWU and Ogechi NWAKANMA}

Department of Biochemistry, University of Nigeria, Nsukka, Nigeria

Received 11 August 2007

MS/No BKM/2007/036, ( 2008 Nigerian Society for Experimental Biology. All rights reserved.

\begin{abstract}
The effect of ethanol extract of Pyrenacantha staudtii leaves on carbontetrachloride $\left(\mathrm{CCl}_{4}\right)$ induced hepatotoxicity in rats was studied. Sixteen male wistar rats of 100-170g body weight divided into four groups of four rats each, designated - group I, II, III and IV were used. Groups II, III and IV were injected intraperitoneally with $5 \mathrm{ml} / \mathrm{kg}$ body weight of $\mathrm{CCl}_{4}$; control was injected with $5 \mathrm{ml} / \mathrm{kg}$ body weight corn oil. After $48 \mathrm{hrs,} \mathrm{groups} \mathrm{III} \mathrm{and} \mathrm{IV} \mathrm{were} \mathrm{administered}$ with $750 \mathrm{mg} / \mathrm{kg}$ and $1500 \mathrm{mg} / \mathrm{kg}$ body weight of the extract respectively and the rats sacrificed after 5 days. Phytochemical analysis of the extract revealed the presence of alkaloids, glycosides, saponnins, carbohydrates, tannins, flavonoids and resin. Result from the study showed that both concentrations of the extract $(750 \mathrm{mg} / \mathrm{kg}$ and $1500 \mathrm{mg} / \mathrm{kg}$ body weight) significantly reduced $(\mathrm{P}<$ 0.05) $\mathrm{CCl}_{4}$ induced elevations in the liver enzymes- alanine aminotransferase (ALT) and Aspartate aminotransferase (AST) in a dose dependent manner. $\mathrm{CCl}_{4}$ induced increases in total and conjugated bilirubin were also significantly lowered by the extract. These results show that the extract of Pyrenacantha staudtii leaves has protective effect against $\mathrm{CCl}_{4}$ induced liver toxicity and damage.
\end{abstract}

Keywords: Pyrenacantha staudtii, ethanol extract, rats, liver toxicity

*To whom correspondence may be addressed. E-mail: chiomanos@yahoo.com Tel: +2348037785462 


\section{INTRODUCTION}

The use of plants in Nigerian traditional medicine as either extracts or infusion is a common practice in the treatment and cure of various types of infections and diseases; respiratory, urinary, skin, gastrointestinal, liver disease, among others ${ }^{1,2}$. Pyrenacantha staudtii plant has been claimed by many traditional medicine practitioners to be effective in the treatment and management of many ailments, such as malaria, ulcer, gastrointestinal tract infections and threatened abortion. This plant which grows by climbing up trees in the tropical rainforest it inhabits, is a shrub characterized by the warty appearance of the inner wall of the endocarp of its fruits ${ }^{3,4}$.

Studies on the pharmacological properties of some of the active components of the plant show that the methanol extract of the leaves has antimalarial properties ${ }^{5}$, exerted high smooth muscle relaxant activity on isolated rat uterus and therefore can be used as a remedy in threatened abortion and dysmenorrhoea ${ }^{6}$. The ethanol extract of the plant was reported to protect rats from developing gastric ulcers induced by various experimental models ${ }^{7}$. From our literature search, no report has been given on the effect of the plant on liver disorders. This study was therefore aimed at evaluating the effect of Pyrenacantha staudtii leaf extract on carbontetrachloride $\quad\left(\mathrm{CCl}_{4}\right) \quad$ induced hepatotoxicity in rats.

\section{MATERIALS AND METHODS}

\section{Animals}

Male Wistar rats of weight $100-170 \mathrm{~g}$ were used for the experiment. They were obtained from the animal house of the Faculty of Biological sciences, University of Nigeria, Nsukka. The rats were maintained ad libitum on water and growers mash bought from Nsukka market.

\section{Plant material}

Pyrenacantha staudtii leaves were collected from the environs of Nsukka, Nigeria and identified by Mr. Alfred Ozioko of the department of Botany, University of Nigeria, Nsukka. Voucher specimens were deposited in the herbarium unit of the department.

\section{Chemicals and Reagents}

Carbontetrachloride $\left(\mathrm{CCl}_{4}\right)$ was purchased from Aldrich Chemical Co. All other chemicals used in this study were of analytical grade and products of May and Baker, England; BDH, England and Merck, Darmstadt, Germany. Reagents used for all the assays were commercial kits and products of Randox, USA; QCA, Spain; Teco (TC), USA; Biosystem Reagents and Instruments, Spain.

\section{Extraction}

The leaves of Pyrenacantha staudtii were dried under room temperature $\left(25^{\circ} \mathrm{C} \pm 15^{\circ} \mathrm{C}\right)$ for two weeks, pulverized into coarse form with a milling machine and macerated in absolute ethanol for $24 \mathrm{hrs}$ before filtering with a white filter cloth. The resulting ethanol extract was evaporated to dryness using a rotary evaporator at an optimum temperature of $40^{\circ} \mathrm{C} \pm 5^{\circ} \mathrm{C}$. The weight of the dry extract was determined $(35.05 \mathrm{~g})$. This was made into 1 litre aqueous solution and stored in the fridge until used.

\section{Phytochemical analysis}

Preliminary phytochemical tests were carried out on the ethanol extract of the leaves using standard methods ${ }^{8,9}$.

\section{Acute toxicity tests}

The acute toxicity tests were carried out by the method of Lorke ${ }^{10}$. The extract was found to be relatively safe. Doses of $750 \mathrm{mg} / \mathrm{kg}$ and $1500 \mathrm{mg} / \mathrm{kg}$ were then chosen as concentrations of the extract to be administered to the rats.

\section{Experimental Design}

Sixteen adult male wistar rats were equilibrated for seven days, randomly divided into four groups of four rats each and housed in separate cages. They were fasted for $12 \mathrm{hrs}$ prior to the experiment. $\mathrm{CCl}_{4}$ was dissolved in corn oil in the ratio of $3: 1(\mathrm{v} / \mathrm{v})$ and administered to the rats. Rats in group I (control) were intraperitoneally injected (i.p.) with $5 \mathrm{ml} / \mathrm{kg}$ corn oil. Rats in groups II, III and IV were injected (i.p.) with $5 \mathrm{ml} / \mathrm{kg} \quad \mathrm{CCl}_{4}$ (single dose). After 48hrs, $750 \mathrm{mg} / \mathrm{kg}$ and $1500 \mathrm{mg} / \mathrm{kg}$ body weight of Pyrenacantha staudtii leaf extract was administered to groups III and IV respectively. The rats were sacrificed after 5 days. 


\section{Preparation of serum}

Blood was obtained from the rats by heart puncture technique into centrifuge tubes. Serum was prepared by centrifugation for $10 \mathrm{mins}$ at 3000rev/hr in a bench centrifuge. The clear supernatant was used for the biochemical tests carried out.

\section{Biochemical analysis}

Serum alanine aminotransferase (ALT), aspartate aminotransferase (AST), and serum alkaline phosphatase were estimated colorimetrically using Randox reagent enzyme kits based on the methods of Reitman and Frankel $^{11}$, and King and Kind ${ }^{12}$ respectively. Total protein based on Lowry ${ }^{13}$ and Bilirubin based on Jendrassic reaction ${ }^{14}$ were also determined using reagent kits.

\section{Statistical analysis}

Data were analysed as mean \pm SD. Difference between means was assessed by a two-tailed Student's T- test. $\mathrm{P}<0.05$ was considered statistically significant.

\section{RESULTS AND DISCUSSION}

Phytochemical analysis of the ethanol extract of Pyrenacantha staudtii leaves (Table 1) show the presence of alkaloids, glycosides, saponnins, carbohydrate, tannins, flavonoids and resins.

Table 1: Result of phytochemical tests of the ethanol extract of Pyrenacantha staudti leaves.

\begin{tabular}{|l|l|}
\hline Constituent & $\begin{array}{l}\text { Relative } \\
\text { abundance }\end{array}$ \\
\hline Alkaloids & ++ \\
\hline Glycosides & +++ \\
\hline Saponnins & + \\
\hline Acid compounds & + \\
\hline Carbohydrates & ++++ \\
\hline Tannins & + \\
\hline Reducing sugar & - \\
\hline Protein & - \\
\hline Flavonoids & +++ \\
\hline Resin & +++ \\
\hline Fats and oil & - \\
\hline Steroids & - \\
\hline Terpenoids & - \\
++++- Abundantly present \\
$+++\quad$ Present in high concentration \\
$++\quad-$ Present in moderate concentration \\
$+\quad-$ Present in small concentration \\
$-\quad$ Absent
\end{tabular}

Phytochemicals such as protein, fats and oil, steroids and terpenoids were however not detected. The extract was also found to be slightly acidic. Earlier studies on the plant ${ }^{6,7}$ also reported the presence of alkaloids, tannins and triterpenoid saponnins from the methanol and ethanol leaf extracts. These secondary metabolites are known to exhibit diverse biochemical and pharmacological effects in animals. Alkaloids present in plants are known to have numerous beneficial pharmacological effects $^{8}$. Some bioflavonoids have been reported to possess antioxidant properties which help to combat free radical induced oxidative stress ${ }^{15}$. Results from the acute toxicity test of the ethanol extract of the plant (Table 2) show that the plant has no toxic effect on the animal $\left(\mathrm{LD}_{50}\right.$ $>5 \mathrm{~g} / \mathrm{kg}$ body weight).

Table 2: Result of acute toxicity test for Pyrenacantha staudti leaf extract.

Phase one

\begin{tabular}{|c|c|c|c|}
\hline Groups & $\begin{array}{c}\text { Number } \\
\text { of mice }\end{array}$ & $\begin{array}{c}\text { Dose } \\
\mathbf{m g} / \mathbf{k g}\end{array}$ & $\begin{array}{c}\text { Dead } \\
\mathbf{( \% )}\end{array}$ \\
\hline 1 & 3 & 10 & 0 \\
\hline 2 & 3 & 100 & 0 \\
\hline 3 & 3 & 1000 & 0 \\
\hline
\end{tabular}

\begin{tabular}{|c|c|c|c|}
\multicolumn{4}{|c}{ Phase two } \\
\hline Groups & $\begin{array}{c}\text { Number } \\
\text { of mice }\end{array}$ & $\begin{array}{c}\text { Dose } \\
\mathbf{m g} / \mathbf{k g}\end{array}$ & $\begin{array}{c}\text { Dead } \\
(\boldsymbol{\%})\end{array}$ \\
\hline 4 & 3 & 1600 & 0 \\
\hline 5 & 3 & 2900 & 0 \\
\hline 6 & 3 & 5000 & 0 \\
\hline
\end{tabular}

An earlier report ${ }^{5}$ also observed no significant toxic effect for the dry aqueous extract of the plant. Results from Table 3, show increases in the liver enzymes - aspartate aminotransferase (AST), alanine aminotransferase (ALT) and alkaline phosphatase (ALP) at the administration of $\mathrm{CCl}_{4}$. Treatment of the animals with different concentrations of the plant extracts $(750 \mathrm{mg} / \mathrm{kg}$ and $1500 \mathrm{mg} / \mathrm{kg}$ body weight) significantly reduced $(\mathrm{P}<0.05)$ the $\mathrm{CCl}_{4}$ induced elevations in AST and ALT. The extract showed no significant effect on alkaline phosphatase. $\mathrm{CCl}_{4}$ is a well known hepatocarcinogenic agent in laboratory animals ${ }^{16}$. Exposure to $\mathrm{CCl}_{4}$ has been reported to induce free radical generation in tissues such as liver, heart, lung, testis, brain and blood $^{17}$. 
Table 3: Effect of the ethanol extract of Pyrenacantha staudti leaves on some biochemical parameters of rats after $\mathrm{CCl}_{4}$ administration.

\begin{tabular}{|c|c|c|c|c|}
\hline \multirow[b]{2}{*}{ PARAMETERS } & \multicolumn{4}{|c|}{ GROUPS } \\
\hline & Control & $\begin{array}{c}\mathrm{CCl}_{4} \\
5 \mathrm{ml} / \mathrm{kg} \text { body } \\
\text { weight }\end{array}$ & $\begin{array}{c}\mathrm{CCl}_{4}+200 \mathrm{mg} / \mathrm{kg} \\
\text { Pyrenacantha } \\
\text { staudti } \text { extract }\end{array}$ & $\begin{array}{l}\mathrm{CCl}_{4}+400 \mathrm{mg} / \mathrm{kg} \\
\text { Pyrenacantha } \\
\text { staudti extract }\end{array}$ \\
\hline $\begin{array}{c}\text { Aspartate } \\
\text { aminotransferase (U/L) }\end{array}$ & $104.75 \pm 20.30^{\mathrm{a}}$ & $127.25 \pm 14.84^{a}$ & $88.50 \pm 8.54^{b}$ & $86.25 \pm 13.32^{b}$ \\
\hline $\begin{array}{c}\text { Alanine aminotransferase } \\
(\mathrm{U} / \mathrm{L})\end{array}$ & $30.00 \pm 5.40^{\mathrm{a}}$ & $42.50 \pm 9.71^{\mathrm{a}}$ & $26.00 \pm 5.66^{b}$ & $21.00 \pm 3.16^{b}$ \\
\hline $\begin{array}{c}\text { Alkaline phosphatase } \\
(\mathrm{U} / \mathrm{L})\end{array}$ & $76.50 \pm 6.35^{\mathrm{a}}$ & $89.75 \pm 5.19^{b}$ & $85.75 \pm 2.21^{\mathrm{a}, \mathrm{b}}$ & $89.75 \pm 9.36^{b}$ \\
\hline Total protein $(\mathrm{g} / \mathrm{dl})$ & $80.00 \pm 4.08^{\mathrm{a}}$ & $67.75 \pm 4.50^{b}$ & $60.75 \pm 7.00^{b, c}$ & $55.25 \pm 7.41^{c}$ \\
\hline Total bilirubin (mg/dl) & $0.23 \pm 0.50^{\mathrm{a}}$ & $0.45 \pm 0.19^{b}$ & $0.22 \pm 0.10^{\mathrm{a}}$ & $0.27 \pm 0.19^{\mathrm{a}}$ \\
\hline $\begin{array}{c}\text { Conjugated bilirubin } \\
(\mathrm{mg} / \mathrm{dl})\end{array}$ & $0.55 \pm 0.25^{\mathrm{a}}$ & $1.15 \pm 0.26^{b}$ & $0.19 \pm 0.07^{\mathrm{a}}$ & $0.19 \pm 0.06^{\mathrm{a}}$ \\
\hline
\end{tabular}

Values are mean $\pm S D$; Results with different superscript $\left({ }^{a, b, c}\right)$ on the same row are statistically significant $(P<0.05)$

The first metabolite of $\mathrm{CCl}_{4}$; trichloromethyl free radical, is believed to initiate the biochemical processes leading to oxidative stress, which is the direct cause of many pathological conditions such as diabetes mellitus, cancer, hypertension, kidney damage, liver damage and death ${ }^{17-19}$. Liver damage caused by acute exposure to $\mathrm{CCl}_{4}$ shows clinical symptoms such as jaundice, swollen and tender liver and elevated levels of liver enzymes in the blood $^{20,21}$. The liver enzymes found within organs and tissues are released into the bloodstream following cellular necrosis and cell membrane permeability and are used as diagnostic measure of liver damage ${ }^{22}$. Result from this study showing a reduction in $\mathrm{CCl}_{4}$ induced elevations of the liver enzymes, at the administration of Pyrenacantha staudtii extract, suggests a protective effect of the extract against $\mathrm{CCl}_{4}$ induced toxicity and therefore amelioration of the liver damage. Total protein concentration of the $\mathrm{CCl}_{4}$ treated rats (Table 3) was significantly reduced $(\mathrm{P}<0.05)$ as compared to control. This suggests a reduction in the protein synthetic function of the liver, which could be as a result of possible damage to the hepatocytes induced by $\mathrm{CCl}_{4}$. Most protein found in the plasma are synthesized by the hepatocytes and secreted into circulation. Reduction in total protein level at the administration of $\mathrm{CCl}_{4}$ to male Fisher rats was also reported ${ }^{20}$. Administration of Pyrenacantha staudti extract lead to an increased reduction in the total protein level in a dose dependent manner as compared to control. This result shows that the extract enhanced, rather than modulate, the reduced protein synthetic function of the liver. We could not explain this trend in the result. Total and conjugated bilirubin levels (Table 3) were significantly increased in the $\mathrm{CCl}_{4}$ treated rats as compared to control. Administration of the extracts $(750 \mathrm{mg} / \mathrm{kg}$ and $1500 \mathrm{mg} / \mathrm{kg}$ body weight $)$ lead to a significant reduction $(\mathrm{P}<0.05)$ in their levels. Report from Tirkey et $a l^{21}$ also showed a marked rise in bilirubin levels after $\mathrm{CCl}_{4}$ administration. Bilirubin, a major breakdown product of haemoglobin rises when there is liver injury or damage; leading to the discolouration of the skin known as jaundice ${ }^{22}$.

Elevation of total bilirubin which results from decreased uptake and conjugation of bilirubin by the liver is caused by liver cell dysfunction, while increased levels of direct or conjugated bilirubin is due to decreased secretion from the liver or obstruction of the bile ducts ${ }^{22}$. Reduction of $\mathrm{CCl}_{4}$ induced increases in total and conjugated bilirubin by Pyrenacantha staudti extract further show its protective effect against $\mathrm{CCl}_{4}$ induced liver toxicity. The extract perhaps protects the liver cell from damage, thereby enhancing bilirubin uptake and conjugation by the liver and subsequent secretion into the bile ducts. These reports from our study show that the ethanol extract of Pyrenacantha staudti possess antihepatotoxic activity as demonstrated 
by its reduction of $\mathrm{CCl}_{4}$ induced elevations in the levels of ALT, AST, total and conjugated bilirubin. This hepatoprotective effect suggests that the plant may also possess antioxidant properties that helped to combat the $\mathrm{CCl}_{4}$ induced oxidative stress in the liver. The ability of natural compounds to attenuate carcinogen induced hepatotoxicity is believed to be related to their intrinsic antioxidant properties ${ }^{23}$. Phytochemical result from this study revealed the presence of flavonoids, which has been reported to protect against toxicity induced by environmental toxicants ${ }^{23}$ such as $\mathrm{CCl}_{4}$. The chemoprotective activities of flavonoids are related to their ability to inhibit peroxidative damage caused by environmental toxicants. In conclusion, the flavonoids present in Pyrenacantha staudti plant may have, perhaps, played a major role in the hepatoprotective action of the plant.

\section{REFERENCES}

1.Iwu, M. M. (1982) Traditional Igbo medicine. Pp. 104. Institute of African Studies, University of Nigeria, Nsukka.

2.Iwu, M. M. (1993) Handbook of African medicinal plants. Pp. 1. CRC Press, Inc Florida.

3.Lambo, J. A. (1984) Medicinal plants in tropical West Africa. Pp. 142-144. Cambridge University Press.

4.Heywood, V. H. (1992) Taxonomy, Biosystematics and Conservation. In: Conservation Biology - A training manual for Biological, Diversity and Genetic Resources. P. Kapoor - Vijay and J. White (eds.), pp. 95-101. The Common Science Council, Commonwealth Secretariat, London.

5.Mesia, G. K., Toma, G. L., Penge, O., Lusakibanza, M., Nanga, T. M., Cimanga, R. K., Apers, S., Van, M. S., Totte, J., Pieters, L. and Vlietinck, A. J. (2005) Antimalarial activities and toxicities of three plants used as traditional remedies for malaria in the Democratic Republic of Congo: Croton mubango, Nuclea pobeguinii and Pyrenacantha staudtii. Annals of Tropical medicine and parasitology. 99:345-357(3).
6.Falodun, A., Usifoh, C. O. and Nworgu, Z. A. (2005) Phytochemical and active column fractions of pyrenacantha staudtii leaf extracts on isolated rat uterus. Pak. $J$. Pharm Sci. 18 (4):31-35.

7.Aguwa, C. N. and Okunji, C. O., (1986) Gastrointestinal studies of Pyrenacantha staudtii leaf extracts. J. Ethanopharmacol. 151(1):45-55.

8.Harbone, J. B. C. (1973) Phytochemical methods. P.279. Chapman and Hall, London.

9.Trease, G. E. and Evans, W. C. (1983) Phenols and Phenolic glycosides. In: Textbook of Pharmacognosy. (12 ${ }^{\text {th }}$ ed.), pp. 343-383. Balliese, Tindall and Co Publishers, London.

10.Lorke, D. (1983) A new approach to practical acute toxicity testing. Arch. Toxicity. 54:275 - 287.

11.Reitman, S. and Frankel, S. (1957) A colorimetric method for the determination of serum glutamate - oxaloacetic acid and glutamate - pyruvic acid transaminases. Amer J. Clin Path. 28:56-63.

12.King, E. J. and Kind, R. P. N. (1954) Alkaline phosphatase activity assay. Clin Path. 7:332.

13.Lowry, O. H., Rosenbrough, N. J., Farr, L. and Randall, R. J. (1951) Protein measurement with folin phenol reagent. $J$. Biol. Chem. 193:265-275.

14.Jendrassic, L. and Grof, P. (1938) A colorimetric method for the determination of serum bilirubin level. Biochem $J$. 297:81.

15.Farombi, E. O., Akanni, O. O. and Emerole, G. O. (2001) Antioxidant and Scavanging activities of flavonoid extract (kolaviron) of Garcinia kola seeds in vitro. Pharmaceutical Biology.47:31633168.

16.Guven, A., GuvenA. and Gulmez, M. (2003) The effect of kefir on the activities of GSH-PX, GST, CAT, GSH, and LPO levels in carbontetrachloride - induced mice tissues. J. Vet Med B Infect Dis Vet Public Health. 50:412-416.

17.Ahmed, F.F., Cowan, D. L. and Sun, A Y. (1987) Detection of free radical formation in various tissue after acute 
carbontetrachloride administration in gerbil. Life Sci. 41:2469-2475.

18.Pohl, L., Schuliek, R. and George, J. (1984) Reductive oxygenation mechanism of metabolism of carbontetrachloride phosgene by cytochrome p-450. Mol Pharmacol. 25: 318-324.

19.Kurata, M., Suzuku, M. and Agar, N. S. (1993) Antioxidant systems and erythrocyte life span in mammals. Comp Biochem Physiol. 106B:477-487.

20.Allis, J. W., Ward, T. R., Seely, J. C. and Simmons, J. E. (1990) Assessment of hepatic indicators of subchronic carbon tetrachloride injury and recovery in rats. Fundam Appl Toxicol. 15:558-570.

21.Tirkey, Pukhwal, S., Kuhad, A. and Chopra, K. (2005) Hesperidin, a citrus bioflavonoid, decreases the oxidative stress produced by carbontetrachloride in rat liver and kidney. BMC Pharmacol. 5: 2-6 doi 10. 1186/1471-2210-5-2.

22.Sanjiv, C. (2002) The liver book: A comprehensive guide to diagnosis, treatment and recovery. Atria Jimcafe Company.

23.Farombi, E. O. (2003) Locally derived natural antioxidant substances in Nigeria: Potential role as new chemotherapeutic agents. In: Molecular and Therapeutic Aspects of Redox Biochemistry. Theeshan Bahorun and Ameenah Gurib-Fakim (eds.), pp 208-225. OICA International (UK) Limited 